\title{
PADAT PENEBARAN BERBEDA TERHADAP KELANGSUNGAN HIDUP, FCR DAN PERTUMBUHAN IKAN BAWAL AIR TAWAR (Colossoma macropomum) PADA PEMELIHARAAN DI WARING
}

\author{
Different Stocking Densities on Feed Convention Ratio, Survival Rate and Growth \\ of Freshwater Pomfret on Maintenance in the Net \\ Detri Arianto $^{1}$, Helmi Harris ${ }^{1}$, Indah Anggraini Yusanti ${ }^{1}$ dan Arumwati ${ }^{2}$ \\ 1) Program Studi Perikanan Fakultas Perikanan Universitas PGRI Palembang \\ 2) Satuan Pengawasan Sumber Daya Kelautan dan Perikanan Palembang \\ Email : indahayusanti@gmail.com
}

\begin{abstract}
Abstrak
Penelitian ini bertujuan untuk mengetahui pertumbuhan dan kelangsungan hidup Ikan Bawal Air Tawar (Colossoma macropomum) pada peliharaan di waring dengan padat tebar yang berbeda. Penelitian ini dilaksanakan di Kampus C Fakultas Perikanan Universitas PGRI, Kelurahan Srimulia Kecamatan Sematang Borang Palembang. Ikan uji yang digunakan adalah Ikan Bawal Air Tawar dengan panjang awal $4-5 \mathrm{~cm}$ dengan berat awal 0,95 -1,65 gram, yang dipelihara di waring berukuran $1 \mathrm{~m} \times 1 \mathrm{~m} \times 1,2 \mathrm{~m}$. Metode penelitian yang digunakan adalah metode eksperimen dengan menggunakan Rancangan Acak Lengkap (RAL), terdiri 5 taraf perlakuan dengan 3 kali ulangan. Hasil penelitian menunjukkan, bahwa perlakuan A (Padat tebar $10 \mathrm{ekor} / \mathrm{m}^{2}$ ) menunjukkan pertumbuhan tertinggi yaitu 12,47 gram, dengan panjang 10,4 cm, kelangsungan hidup 100\%, dan FCR sebesar 0,70. Pertumbuhan terendah ada pada perlakuan E (padat tebar $50 \mathrm{ekor} / \mathrm{m}^{2}$ ) yaitu 8,09 gram, dengan panjang $3,5 \mathrm{~cm}$, kelangsungan hidup $97 \%$ dan FCR sebesar 0,82. Hasil pengamatan kualitas air yang diukur selama penelitian masih dalam batas toleransi untuk tumbuh dan berkembang Ikan Bawal Air Tawar. Dari hasil penelitian yang dilakukan diketahui padat tebar terbaik untuk pertumbuhan dan kelangsungan hidup dalam pemeliharaan Ikan Bawal Air Tawar adalah perlakuan A (padat tebar $10 \mathrm{ekor} / \mathrm{m}^{2}$ ) yaitu dengan rata-rata berat mutlak sebesar 12,47 gram, laju pertumbuhan 0,25 gram/hari panjang mutlak $10,4 \mathrm{~cm}$, laju pertambahan panjang 0,12 $\mathrm{cm} /$ hari, kelangsungan hidup $100 \%$.
\end{abstract}

Kata Kunci: Ikan Bawal Air Tawar, Padat Tebar, Pertumbuhan, Kelangsungan Hidup

\begin{abstract}
This study aims to determine the growth and survival of seed Freshwater Pomfret Fish (Colossoma macropomum) were maintained in the net with different stocking densities. This study was conducted on the campus of the University of PGRI C Faculty of Fisheries, Sub District of Sri Mulia Palembang. The fish samples used was Freshwater Pomfret Fish with $4-5 \mathrm{~cm}$ initial length with initial weight of 0.95 $1.65 \mathrm{~g}$, which is maintained in measuring $1 \mathrm{~m} \times 1 \mathrm{~m}$ waring $\times 1.2 \mathrm{~m}$. The method used is an experimental method using a completely randomized design (CRD), comprising 5 stage treatment with 3 replications. The results showed that treatment A (Solid stocking 10 fish $/ \mathrm{m}$ 2) showed the highest growth of 12.47 grams, with a length of $10.4 \mathrm{~cm}, 100 \%$ survival, and FCR of 0.70. Lowest growth is in treatment $E$ (stocking density $50 \mathrm{fish} / \mathrm{m}^{2}$ ) is 8.09 grams, with a length of $3.5 \mathrm{~cm}$, 97\% survival and FCR of 0.82 . The observation of water quality measured during the study are still within the limits of tolerance for the seed to grow and evolve Bawal Freshwater Fish. From the research that is done is known best stocking density for growth and survival in maintenance Freshwater pomfret fish seed is treatment A (stocking density 10 fish $/ \mathrm{m}^{2}$ ) is the average of the absolute weight of 12.47 grams, 0.25 growth rate grams / day of absolute length of $10.4 \mathrm{~cm}$, the rate of increase in length of $0.12 \mathrm{~cm} /$ day, the survival of $100 \%$.
\end{abstract}

Keywords: Freshwater pomfret fish, Growth, Survival Rate 


\section{PENDAHULUAN}

Ikan Bawal Air Tawar (Colossoma macropomum) merupakan salah satu komoditas ikan air tawar yang bernilai ekonomis tinggi, baik sebagai ikan konsumsi maupun ikan hias. Sebagai ikan konsumsi, ikan Bawal Air Tawar memiliki rasa daging enak dan gurih sehingga disukai oleh konsumen. Keistimewaan itu membuat banyak pembudidaya ikan yang membudidayakan sehingga menjadi peluang usaha yang menguntungkan (Arie, 2009). Kegiatan pembenihan ikan Bawal Air Tawar sangat menunjang dalam kegiatan pembesaran. Suplai benih ikan Bawal Air Tawar di Indonesia dipengaruhi oleh musim, yaitu pada musim penghujan benih bawal melimpah sedangkan pada musim kemarau sangat sedikit. Salah satu solusi untuk meningkatkan suplai benih ikan Bawal Air Tawar adalah dengan cara pemeliharaan secara intensif melalui peningkatan padat tebar.

Hasil penelitian Yulianti (2007) pada padat tebar 10 ekor/liter benih ikan Bawal Air Tawar berukuran kuku dengan bobot $0,17 \pm 0,01 \mathrm{~g}$ dan panjang 1,78 $\pm 0,04 \mathrm{~cm}$. dalam waktu 40 hari didapat pertumbuhan spesifik $7,53 \%$, pertumbuhan panjang mutlak $2,71 \mathrm{~cm}$, dan derajat kelangsungan hidup berkisar 99,07\%. Selanjutnya Arie (2009) menambahkan untuk benih ukuran berukuran 1,25 inci $(3,175 \mathrm{~cm})$, masa pemeliharaan 40 hari dapat ditebar dengan kepadatan $12 \mathrm{ekor} / \mathrm{m}^{2}$. Peningkatan kepadatan tebar yang melebihi carrying capacity akan menyebabkan penurunan laju pertumbuhan. Hal ini sesuai dengan pernyataan Hepher dan Pruginin (1981) dalam Yulianti (2007), bahwa peningkatan kepadatan akan diikuti dengan penurunan pertumbuhan dan pada kepadatan tertentu pertumbuhan akan terhenti. Untuk mencegah hal tersebut, maka dibutuhkan informasi padat tebar yang optimum sehingga diharapkan dapat memberi hasil yang maksimal terhadap pertumbuhan, FCR dan kelangsungan hidup ikan Bawal Air Tawar (Colossoma macropomum).

\section{METODE PENELITIAN}

\section{Waktu dan Tempat Penelitian}

Penelitian ini telah dilakukan selama 49 hari bertempat di Kampus C Fakultas Perikanan Universitas PGRI Kelurahan Sri Mulia Kecamatan Sematang Borang Palembang.

\section{Metode Penelitian}

Penelitian ini menggunakan Rancangan Acak Lengkap (RAL) dengan 5 taraf perlakuan dan masing-masing perlakuan terdiri atas 3 ulangan. Perlakuan yang dilakukan adalah sebagai berikut:
$\mathrm{A}=$ Padat tebar bawal air tawar 10 ekor $/ \mathrm{m}^{2}$
$\mathrm{B}=$ Padat tebar bawal air tawar $20 \mathrm{ekor} / \mathrm{m}^{2}$
C = Padat tebar bawal air tawar 30 ekor $/ \mathrm{m}^{2}$
$\mathrm{D}=$ Padat tebar bawal air tawar 40 ekor $/ \mathrm{m}^{2}$
$\mathrm{E}=$ Padat tebar bawal air tawar 50 ekor $/ \mathrm{m}^{2}$
3. Analisis Data
a. Pertumbuhan Berat

Perhitungan pertambahan berat dan panjang Ikan Bawal (Colossoma macropomum) dilakukan seperti yang di kemukakan Effendie (1979) sebagai berikut :$$
\text { Keterangan : }
$$$$
\mathrm{W}=\text { Pertambahan berat (gr) }
$$$$
\mathrm{Wt} \quad=\text { Berat rata-rata ikan pada akhir }(\mathrm{gr})
$$$$
\text { Wo = Berat rata-rata ikan pada awal (gr) }
$$$$
\text { b. Pertumbuhan Panjang : }
$$$$
\mathbf{T}=\mathbf{L t}-\mathbf{L o}
$$

Keterangan :

$\mathrm{T}=$ Pertambahan panjang $(\mathrm{cm})$

$\mathrm{Lt}=$ Panjang rata-rata ikan pada akhir $(\mathrm{cm})$

Lo $=$ Panjang rata-rata ikan pada awal $(\mathrm{cm})$

c. Feed Convention Ratio (FCR)

Untuk mengetahui jumlah pakan yang digunakan selama pemeliharaan dapat dihitung menggunakan rumus Effendie (1979) yaitu :

$$
\mathbf{F} /\left(\mathbf{W}_{\mathbf{t}}+\mathbf{D}\right)-\mathbf{W}_{\mathbf{o}}
$$

Keterangan :

$$
\begin{array}{ll}
\mathrm{F} & =\text { Total pakan yang digunakan }(\mathrm{gr}) \\
\mathrm{Wt} & =\text { Berat Total Akhir pemeliharaan }(\mathrm{gr}) \\
\mathrm{Wo} & =\text { Berat Total Awal pemeliharaan }(\mathrm{gr}) \\
\mathrm{D} & =\text { Berat Total ikan mati / mortalitas }(\mathrm{gr})
\end{array}
$$

\section{d. Kelangsungan Hidup (SR)}

Pengamatan kelangsungan hidup Ikan Bawal (Colossoma macropomum) menggunakan rumus yang dikemukakan Effendie (1979).

$$
\mathbf{S R}=\frac{\mathbf{N t}}{\mathbf{N}_{\mathrm{o}}} \times 100 \%
$$

Keterangan :

$$
\begin{aligned}
& \mathrm{SR} \quad=\text { Derajat kelulusan hidup (\%) } \\
& \mathrm{Nt} \quad=\text { Jumlah pada akhir pemeliharaan (ekor) } \\
& \mathrm{No} \quad \text { = Jumlah pada awal penebaran (ekor) } \\
& \text { e. Kualitas Air }
\end{aligned}
$$

\section{e. Kualitas Air}

Parameter kualitas air yang diukur meliputi suhu, $\mathrm{pH}$, oksigen terlarut (DO) dan $\mathrm{NH}_{3}$.

Data yang diperoleh dari hasil pengamatan selama penelitian akan dianalisis sidik ragam (ANOVA) pada taraf 5\% dan 1\% (Hanafiah, 1995).

\section{HASIL DAN PEMBAHASAN}

\section{Pertumbuhan Berat}

Berdasarkan penelitian yang telah dilakukan selama 7 minggu diperoleh data pertumbuhan berat mutlak (g) ikan Bawal disajikan pada Gambar 1 berikut : 


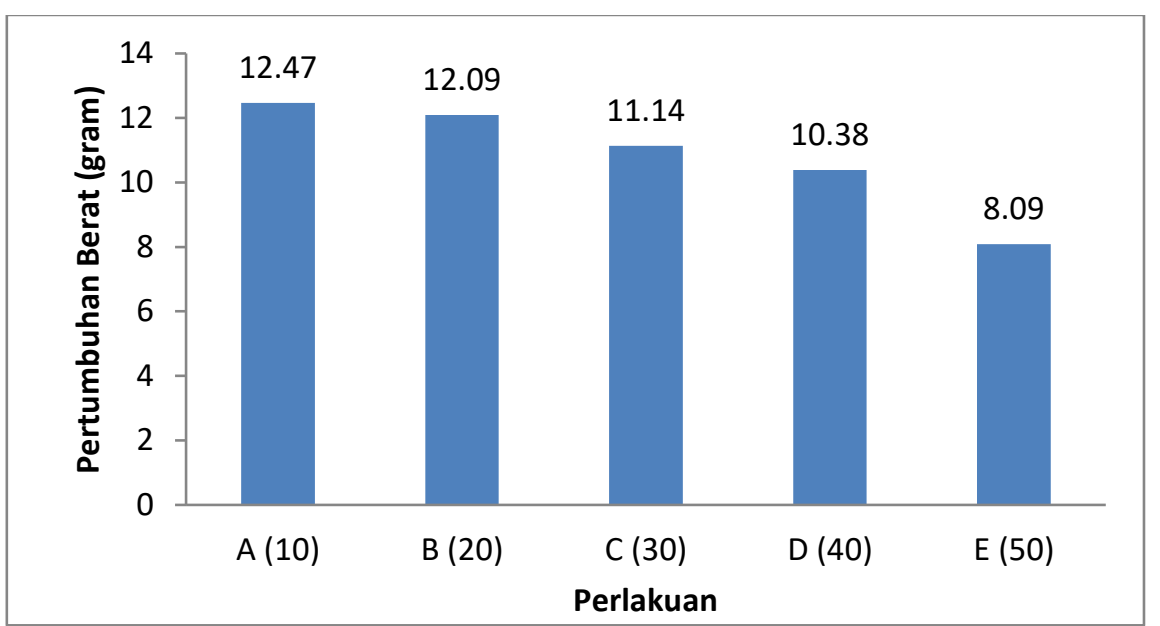

Gambar 1. Grafik Pertumbuhan Berat (gr) Ikan Bawal Air Tawar (Colossoma macropomum)

Dari Gambar 1 diatas dapat dilihat bahwa, berat rata-rata Ikan Bawal Air Tawar (Colossoma macropomum) pada akhir masa pemeliharaan berkisar antara 8,09 gram hingga 12,47 gram. Terdapat adanya peningkatan berat pada setiap perlakuan, dimana pertumbuhan berat tertinggi yaitu pada perlakuan A dengan padat tebar 10 ekor $/ \mathrm{m}^{2}$ sebesar 12,47 gram. Sedangkan pertumbuhan berat terendah yaitu pada perlakuan E dengan padat tebar $50 \mathrm{ekor} / \mathrm{m}^{2}$ yaitu 8,09 gram. Menurunnya pertumbuhan berat ikan disebabkan meningkatnya padat tebar dan ruang gerak ikan yang semakin sempit, sehingga peluang memperoleh pakan akan semakin kecil, walaupun pakan tersedia tetapi ikan tidak dapat menjangkau pakan karena adanya persaingan dengan ikan lainnya.

Hasil analisis keragaman dari pengamatan berat ikan selama penelitian didapatkan bahwa nilai $F_{\text {hitung }} 13,868>F_{\text {tabel }} 0,01 \%$ 5,98, maka dapat disimpulkan bahwa perlakuan perbedaan padat tebar berpengaruh sangat nyata pada selang kepercayaan $99 \%$. Karena Koefisien keragamannya $(\mathrm{KK})>5 \%$, maka dilakukan uji lanjut menggunakan Uji Beda Nyata Terkecil (BNT) $1 \%$. Dari uji BNT 1\% diketahui bahwa perlakuan A (padat tebar 10 ekor $/ \mathrm{m}^{2}$ ) berbeda tidak nyata dengan perlakuan B (padat tebar 20 ekor $/ \mathrm{m}^{2)}$ dan perlakuan C, tetapi berbeda dengan perlakuan D dan E. Perlakuan C berbeda tidak nyata dengan perlakuan A,B, dan D, tetapi berbeda sangat nyata dengan perlakuan $\mathrm{E}$. Perlakuan D berbeda tidak nyata dengan perlakuan $\mathrm{C}$, tetapi berbeda sangat nyata dengan perlakuan E, A, dan B. Sedangkan perlakuan E berbeda sangat nyata dengan perlakuan A,B, C dan D.

Perlakuan A (padat tebar 10 ekor $/ \mathrm{m}^{2}$ ) berbeda tidak nyata dengan perlakuan B (padat tebar 20 ekor/ $\mathrm{m}^{2)}$ dan perlakuan C. Hal ini diduga pada perlakuan $\mathrm{A}, \mathrm{B}$ dan $\mathrm{C}$, ikan masih mendapatkan ruang gerak yang cukup sehingga dapat memanfaatkan pakan dengan baik. Pertumbuhan berat ikan Bawal Air Tawar semakin menurun dengan semakin tingginya padat tebar. Menurunnya pertumbuhan berat ikan disebabkan karena ruang gerak ikan yang semakin sempit dan persaingan untuk mendapatkan pakan, sehingga peluang memperoleh pakan akan semakin kecil, walaupun pakan tersedia tetapi ikan tidak dapat menjangkau pakan karena adanya persaingan dengan ikan lainnya. Hal yang sama juga didapat oleh penelitian Bugri (2006) dan Darmawangsa (2008) yang menyatakan bahwa semakin tinggi padat tebar ikan maka laju pertumbuhan bobot semakin menurun.

Perlakuan D (padat tebar 40 ekor $/ \mathrm{m}^{2}$ ) berbeda tidak nyata dengan perlakuan $\mathrm{C}$, artinya tidak terdapat perbedaan signifikan antara perlakuan D dan C. Perlakuan E (padat tebar 50 ekor $/ \mathrm{m}^{2}$ ) menunjukkan berbeda sangat nyata dengan perlakuan A, B, C dan D. Hal ini diduga semakin tinggi padat tebar semakin meningkatkan respon stress pada ikan. Menurut Handajani (2002) dalam Yulianti (2007) mengatakan bahwa peningkatan kepadatan mempengaruhi proses fisiologi dan tingkah laku ikan terhadap ruang gerak yang pada akhirnya dapat menurunkan kondisi kesehatan dan fisiologis ikan. Hal ini didukung dengan sifat ikan bawal yang garang cenderung ganas dan buas, suka menyerang ikan-ikan yang lemah dan berukuran kecil.

\section{Pertumbuhan Panjang}

Data rata-rata pertumbuhan panjang selama 7 minggu diperoleh pertumbuhan Panjang ikan Bawal Air Tawar seperti yang disajikan pada Gambar 2 berikut ini : 


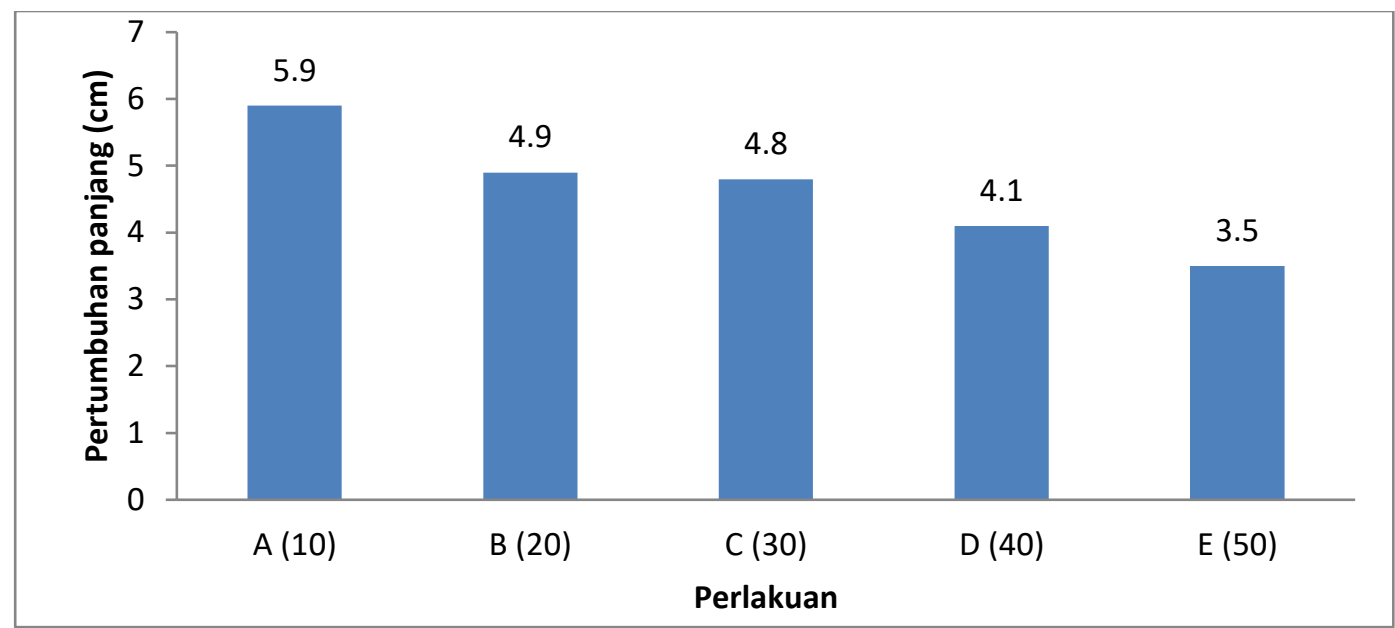

Gambar 2. Grafik Pertumbuhan Panjang Mutlak (cm) Ikan Bawal Air Tawar (Colossoma macropomum).

Dari gambar 2 diatas panjang rata-rata Ikan

Bawal Air Tawar (Colossoma macropomum) pada akhir masa pemeliharaan pertumbuhan panjang berkisar antara $3,5 \mathrm{~cm}$ hingga $5,9 \mathrm{~cm}$. Terdapat adanya pertambahan panjang mutlak pada setiap perlakuan, dimana pertambahan panjang rata-rata tertinggi yaitu pada perlakuan A dengan padat tebar 10 ekor $/ \mathrm{m}^{2}$ Sedangkan pertambahan panjang ratarata terendah yaitu pada perlakuan $\mathrm{E}$ dengan padat tebar $50 \mathrm{ekor} / \mathrm{m}^{2}$. Hal ini diduga penurunan pertumbuhan panjang mutlak seiring dengan meningkatnya padat tebar dan terbatasnya ruang gerak sehingga mempengaruhi nafsu makan ikan di dalam media pemeliharaan.

Dari analisis Sidik Ragam didapatkan bahwa nilai $F_{\text {hitung }} 60,747>F_{\text {tabel }} 0,01 \% 3,49$, maka dapat disimpulkan bahwa perlakuan berbeda sangat nyata pada selang kepercayaan $99 \%$ dengan $\mathrm{KK}=4.27708$ , sehingga dapat di uji lanjut menggunakan metode Beda Nyata Jujur (BNJ) 0,01 \%. Dari hasil uji BNJ $0,01 \%$ tersebut dapat diketahui bahwa perlakuan A (padat tebar $10 \mathrm{ekor} / \mathrm{m}^{2}$ ) berbeda sangat nyata dengan perlakuan B, C, D dan E. Perlakuan B berbeda tidak nyata dengan perlakuan $\mathrm{C}$, artinya tidak terdapat perbedaan signifikan antara perlakuan B dan perlakuan C. Perlakuan D berbeda sangat nyata dengan perlakuan E, A, B dan C. Sedangkan perlakuan $\mathrm{E}$ berbeda sangat nyata dengan perlakuan A, B, C, dan D.

Penurunan pertumbuhan panjang seiring dengan semakin tingginya padat tebar sehingga mempengaruhi nafsu makan ikan di dalam media pemeliharaan. Menurut Hikling (1971) dalam Kusrianto (1996) pertumbuhan ikan lebih cepat bila dipelihara pada padat tebar yang rendah dan sebaliknya pertumbuhan ikan akan lambat bila padat tebar meningkat. Menurut Huet (1971) dalam Sulistyansyah (2013) bahwa pertumbuhan dipengaruhi oleh faktor internal yang terdiri dari daya tahan terhadap penyakit dan genetik, sedangkan faktor eksternal yang berkaitan dengan lingkungan tempat hidup serta ketersediaan makanan

\section{Kelangsungan Hidup}

Dari hasil kegiatan penelitian selama 7 minggu diperoleh kelangsungan hidup Ikan Bawal Air Tawar (Colossoma macropomum) seperti disajikan pada Gambar 3 berikut :

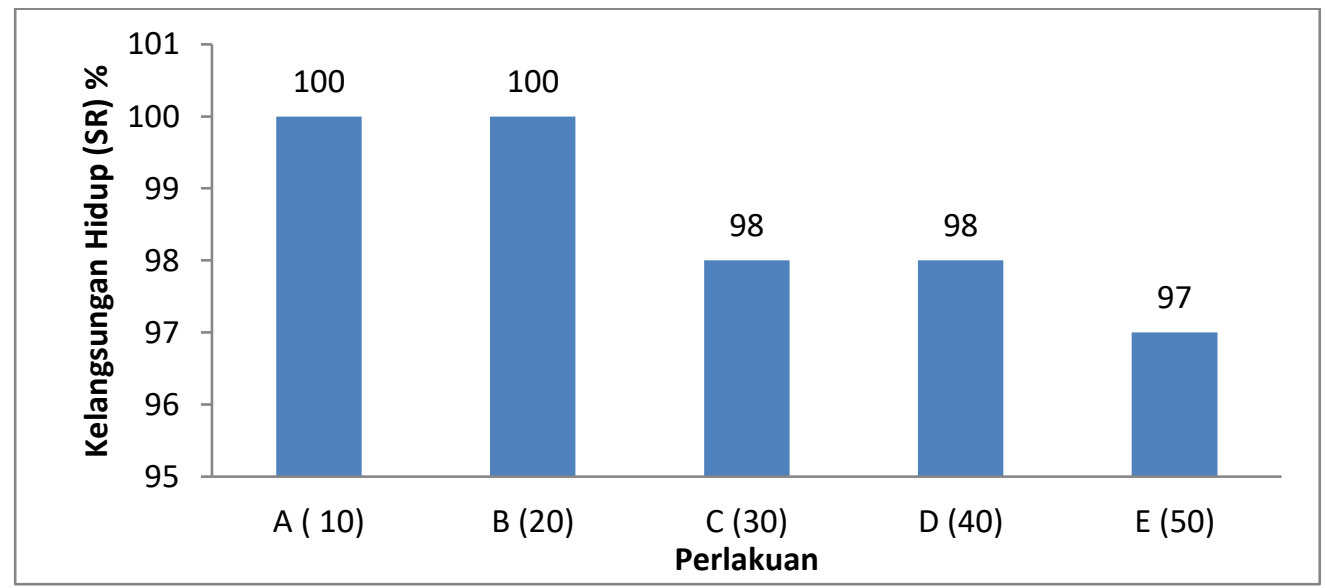

Gambar 3. Grafik Kelangsungan Hidup (SR) Ikan Bawal Air Tawar (Colossoma macropomum) 
Dari gambar 3, diperoleh nilai kelangsungan hidup tertinggi pada perlakuan $\mathrm{A}$ dan $\mathrm{B}$, diikuti oleh perlakuan $\mathrm{D}, \mathrm{C}$ dan $\mathrm{E}$. Rata-rata derajat kelangsungan hidup ikan Bawal Air Tawar pada perlakuan A (padat tebar $10 \mathrm{ekor} / \mathrm{m}^{2}$ ) dan perlakuan B (padat tebar 20 ekor $/ \mathrm{m}^{2}$ ) memiliki derajat kelangsungan hidup yang sama yaitu sebesar $100 \%$ kemudian diikuti perlakuan $\mathrm{C}$ (padat tebar 30 ekor $/ \mathrm{m}^{2}$ ) sebesar $98 \%$ dan perlakuan D (padat tebar $40 \mathrm{ekor} / \mathrm{m}^{2}$ ) yaitu sebesar $98 \%$ kemudian perlakuan E (padat tebar $50 \mathrm{ekor} / \mathrm{m}^{2}$ ) yaitu sebesar $97 \%$.

Hal ini menunjukan bahwa pada perlakuan A dan perlakuan B ikan masih dapat melakukan aktivitas dan tidak membutuhkan energi yang besar untuk beradaptasi terhadap padat tebar, sehingga energi dari makanan dapat digunakan untuk proses pertumbuhan. Kemudian untuk perlakuan C, D, dan E mulai terjadi penurunan kelangsungan hidup hal ini diduga diakibatkan stres sehubungan dengan padat tebar yang semakin tinggi. Hal tersebut ditunjukkan oleh ikan yang tidak responsif terhadap pakan yang diberikan.
Selain itu, diduga padat tebar ikan terlalu tinggi mengakibatkan kompetisi ruang sehingga mengakibatkan kelangsungan hidup menurun. Pada tingkat kepadatan yang terlalu tinggi dapat menyebabkan pertumbuhan individu. Hal ini sesuai dengan pernyataan Bugri (2006) yang mengatakan bahwa kematian yang terjadi pada saat pemeliharaan dikarenakan oleh faktor ruang gerak yang semakin sempit memberikan tekanan stres terhadap ikan pada kepadatan tinggi, dampak dari stres ini mengakibatkan daya tahan tubuh akan menurun dan selanjutnya terjadi kematian. Dari hasil analisis sidik ragam didapatkan bahwa nilai $\mathrm{F}_{\text {hitung }} 2,321<\mathrm{F}_{\text {tabel }}<$ 3,49, maka dapat disimpulkan bahwa perlakuan berbeda tidak nyata dan tidak dilakukan uji lanjut.

\section{Feed Convention Ratio (FCR)}

FCR merupakan rasio jumlah pakan yang diberikan dengan bobot ikan yang dihasilkan. Semakin kecil nilai FCR, maka kegiatan budidaya ikan semakin baik (Effendi, 1979). Berdasarkan hasil sampling di akhir penelitian diperoleh nilai FCR seperti tersaji pada Gambar 4 berikut ini :

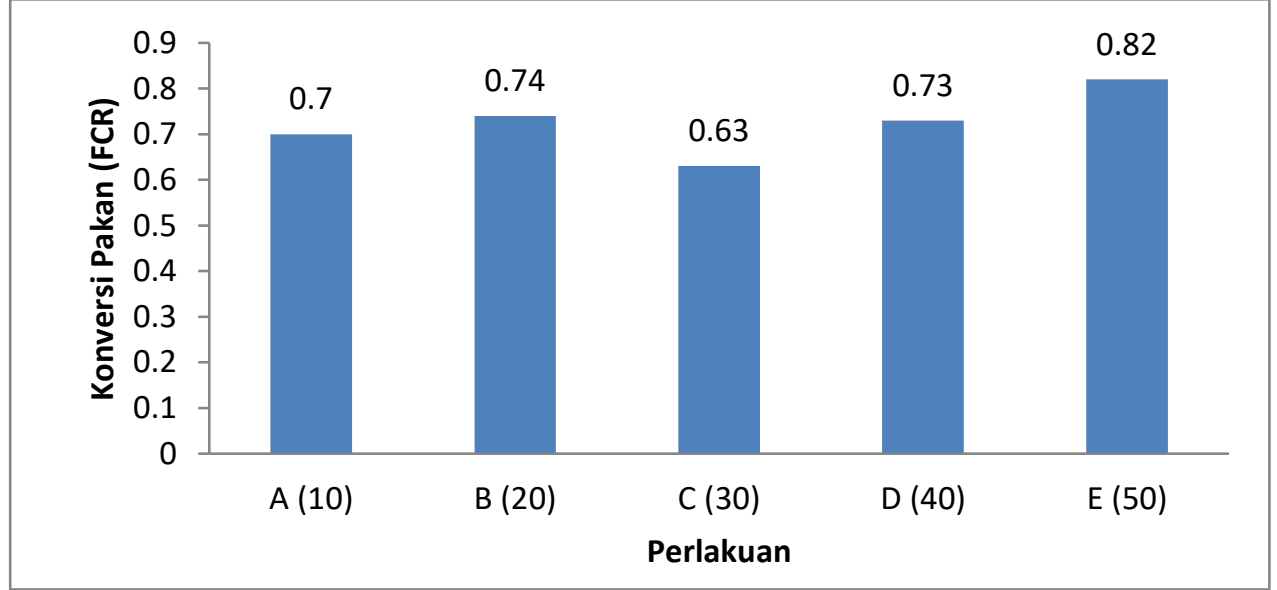

Gambar 4. Grafik Konversi pakan (FCR) Ikan Bawal Air Tawar (Colossoma macropomum)

Berdasarkan penelitian yang telah dilakukan, diperoleh nilai FCR ikan Bawal Air Tawar pada padat tebar yang berbeda yaitu pada perlakuan A (padat tebar $10 \mathrm{ekor} / \mathrm{m}^{2}$ ) 0,70, pada perlakuan B (padat tebar $20 \mathrm{ekor} / \mathrm{m}^{2}$ ) 0,74 , pada perlakuan C (padat tebar 30 ekor $/ \mathrm{m}^{2}$ ) 0,63, kemudian pada perlakuan D (padat tebar $40 \mathrm{ekor} / \mathrm{m}^{2}$ ) dan $\mathrm{E}$ ( padat tebar 50 ekor $/ \mathrm{m}^{2}$ ) masing -masing memiliki nilai FCR sebesar 0,73 dan 0,82 .

Dapat dilihat bahwa nilai FCR terendah terdapat pada perlakuan $C$ yaitu 0,63 dan nilai FCR tertinggi terdapat pada perlakuan $\mathrm{E}$ yaitu 0,82 . Nilai konversi pakan berbanding terbalik dengan pertumbuhan bobot ikan, sehingga semakin rendah nilainya maka semakin baik kualitas pakan dan makin efisien ikan dalam memanfaatkan pakan yang dikonsumsinya untuk pertumbuhan. Selanjutnya Effendi (2004) dalam Santoso dan Hermawansyah
(2011) konversi pakan tergantung pada spesies ikan yang dilihat dari kebiasaan makan, dan ukuran tubuhnya. Selain itu konversi pakan juga dipengaruhi oleh kualitas air, serta kualitas pakan yang diberikan. Lebih lanjutnya Minggawati (2006) menyatakan bahwa konversi pakan dan laju pertumbuhan juga bergantung pada kandungan nutrien yang terdapat pada pakan. Untuk memperoleh pertumbuhan yang optimal, pakan ikan harus mengandung gizi yang cukup. Makanan ikan sebagian besar dipergunakan sebagai sumber energi dan mempertahankan kondisi kekebalan tubuh, sedangkan selebihnya digunakan untuk pertumbuhannya.

Di tinjau dari perhitungan ekonomis, perlakuan $\mathrm{C}$ lebih aplikatif diterapkan di masyarakat, yaitu seperti perhitungan pada Tabel 1 . 
Tabel 1. Analisis Ekonomis Pengunaan Pakan pada masing-masing Perlakuan.

\begin{tabular}{ccccc}
\hline Perlakuan & FCR & $\begin{array}{c}\text { Jumlah pakan yang dibutuhkan untuk } \\
\text { menghasilkan 1 kg daging ikan (kg) }\end{array}$ & $\begin{array}{c}\text { Harga } \\
\text { pakan/kg(Rp) }\end{array}$ & $\begin{array}{c}\text { Kebutuhan biaya pakan } \\
(\mathbf{R p})\end{array}$ \\
\hline A & 0,70 & 0,70 & 15.000 & 10.500 \\
B & 0,74 & 0,74 & 15.000 & 11.100 \\
C & 0,63 & 0,63 & 15.000 & 9.450 \\
D & 0,73 & 0,73 & 15.000 & 10.950 \\
E & 0,82 & 0,82 & 15.000 & 12.300 \\
\hline
\end{tabular}

Dari tabel 1 diatas dapat dilihat bahwa dari perlakuan yang dicobakan, perlakuan $\mathrm{C}$ mempunyai nilai terendah yaitu $\mathrm{Rp} 9.450,-$ dan selanjutnya diikuti oleh perlakuan A Rp 10.500,- perlakuan D Rp 10.950,- perlakuan B Rp 11.100,- dan perlakuan E Rp 12.300,- . jadi, jika diaplikatifkan ke masyarakat, maka diperoleh bahwa perlakuan $\mathrm{C}$ yang terbaik.

Tabel 2. Kisaran Kualitas Air selama 7 Minggu.

\begin{tabular}{ccccc}
\hline Perlakuan & \multicolumn{4}{c}{ Parameter } \\
\cline { 2 - 5 } & Suhu $\left.\mathbf{(}^{\mathbf{0}} \mathbf{C}\right)$ & $\mathbf{p H}$ & $\mathbf{D O}\left(\mathbf{m g L}^{\mathbf{- 1}}\right)$ & Amoniak $\left._{(\mathbf{m g L}} \mathbf{- 1}\right)$ \\
\hline A & $28-32$ & $7-7,5$ & $4,12-4,28$ & $0,014-0,048$ \\
B & $27-33$ & $6,5-7$ & $4,62-4,98$ & $0,015-0,089$ \\
C & $27-31$ & $7-7,5$ & $4,54-5,10$ & $0,017-0,096$ \\
D & $27-32$ & $6,9-7,1$ & $4,54-5,10$ & $0,022-0,104$ \\
E & $29-33$ & $6,5-7,2$ & $4,54-5,88$ & $0,034-0,107$ \\
\hline
\end{tabular}

Dari Tabel 2 diatas, nilai kualitas air selama penelitihan masih berada pada kisaran toleransi yang dapat mendukung kehidupan ikan Bawal Air Tawar, yaitu suhu air selama penelitian yaitu $27-33^{\circ} \mathrm{C}, \mathrm{pH}$ berkisar antara 6,5 -7,5, oksigen terlarut antara 4-125,88 dan amoniak berkisar antara 0,014 - 0,107 $\mathrm{mg} / \mathrm{L}$. Saat pemeliharaan suhu pada media pemeliharaan masih dalam batas toleransi untuk pertumbuhan ikan yaitu berkisar $27^{\circ} \mathrm{C}-33^{\circ} \mathrm{C}$. Berdasarkan penelitian Effendi (2006) dalam Sulistyansyah (2013) kisaran suhu optimal untuk ikan bawal antara 29-32 ${ }^{\circ}$ C. Pertumbuhan Bawal Air Tawar akan jauh berkurang apabila suhu air turun dibawah $25^{\circ}$ C. Wihardi et al (2014), suhu air sangat mempengaruhi laju pertumbuhan, laju metabolisme ikan dan nafsu makan ikan serta kelarutan oksigen dalam air

Selama pemeliharaan $\mathrm{pH}$ pada kolam media hidup ikan masih dalam batas toleransi untuk pertumbuhan ikan berkisar antara 6,5 - 7,5. Ikan bawal dapat tumbuh dengan baik pada kisaran $\mathrm{pH}$ 68 , oksigen terlarut saat pemeliharaan masih dalam batas toleransi berkisar 4,12-5,88 $\mathrm{mgL}^{-1}$. Menurut Kordi (2011) kisaran oksigen terlarut untuk ikan Bawal Air Tawar yaitu berkisar $4-6 \mathrm{mgL}^{-1}$. Pendapat ini didukung oleh Arie (2009) yang menyatakan bahwa konsentrasi oksigen terlarut yang sesuai untuk pemeliharaan ikan Bawal Air Tawar sebaiknya minimal $4 \mathrm{mg} / \mathrm{L}$. Menurut Manurung et al (2018), DO dipengaruhi oleh suhu, $\mathrm{pH}$ dan bahan organik. Semakin tinggi suhu, DO akan semakin rendah. DO yang terlalu rendah dapat disebabkan

\section{Kualitas Air}

Kisaran data parameter kualitas air meliputi suhu, $\mathrm{pH}$, oksgen terlarut (DO) dan amoniak $\left(\mathrm{NH}_{3}\right)$ selama pemeliharaan dapat dilihar pada Tabel 2 berikut ini. oleh lumut, plankton yang mati, kekentalan air serta jumlah bahan organik yang menumpuk.

Selain parameter suhu, $\mathrm{pH}$ dan Oksigen terlarut (DO), juga dilakuan pengujian amoniak $\left(\mathrm{NH}_{3}\right)$. Jumlah amoniak pada media pemeliharaan berkisar 0,012 -0,104 $\mathrm{mgL}^{-1}$. Amoniak merupakan racun bagi ikan sekalipun pada konsentrasi yang sangat rendah. Namun menurut Effendi (2003), toleransi amoniak bagi biota perairan termasuk ikan Bawal adalah tidak lebih dari $0,2 \mathrm{mgL}^{-1}$.

\section{KESIMPULAN DAN SARAN}

\section{Kesimpulan} adalah:

Kesimpulan yang diperoleh dari penelitian ini

a. Padat tebar yang berbeda memberikan pengaruh terhadap pertumbuhan tetapi berpengaruh tidak nyata terhadap FCR dan kelangsungan hidup benih ikan Bawal Air Tawar.

b. Padat tebar terbaik untuk pertumbuhan, kelangsungan hidup benih ikan bawal air tawar adalah pada perlakuan A (padat tebar $10 \mathrm{ekor} / \mathrm{m}^{2}$ ) yaitu dengan rata-rata berat mutlak sebesar 12,47 g, panjang mutlak $5,9 \mathrm{~cm}$, kelangsungan hidup mencapai 100\% dan nilai FCR sebesar 0,70.

\section{Saran}

Perlu dilakukan penelitian lebih lanjut untuk mengatahui bagaimana pengaruh padat tebar terhadap pertumbuhan, kelangsungan hidup dan FCR pada pembesaran ikan Bawal Air Tawar untuk ikan konsumsi. 


\section{DAFTAR PUSTAKA}

Arie, U. 2009. Panen Bawal 40 Hari. Penebar Swadaya. Jakarta.

Bugri, J. 2006. Pengaruh Padat Penebaran Terhadap Kelangsungan Hidup Dan Pertumbuhanbenih Ikan Gurame (Osphronomus goramy) LAC. Ukuran 2 CM Skripsi. Institut Pertanian Bogor (Tidak dipublikasikan).

Darmawangsa, GM. 2008. Pengaruh Padat Penebaran 10, 15 dan 20 ekor/l terhadap Kelangsungan Hidup dan Pertumbuhan Benih Ikan Gurami Osphronemus gouramy Lac. ukuran $2 \mathrm{~cm}$. [Skripsi]. Bogor: Program Studi Teknologi dan Manajemen Akuakultur, Departemen Budidaya Perairan, Fakultas Perikanan dan Ilmu Kelautan, Institut Pertanian Bogor (Tidak dipublikasikan).

Effendi H. 2003. Telaah Kualitas Air bagi Pengelolaan Sumberdaya dan Lingkungan. Perairan. Kanisius. Yogyakarta.

Effendie, M. I. 1979. Biologi Perikanan. Yayasan Pustaka Nusatama. Yogyakarta

Hanafiah, K. A. 1995. Rancangan Percobaan Teori dan Aplikasi. Edisi Revisi. Fakultas Pertanian Universitas Sriwijaya. Palembang.

Kordi, K.M.G.H., 2011. Budidaya Bawal Air Tawar. Akademia, Jakarta.

Kusrianto, B. 1996. Pengaruh Padat Tebar Terhadap Pertumbuhan Dan Kelangsungan Hidup Benih Ikan Patin Bangkok (Pangasius sutchi fowler) Dipelihara Dalam Jaring Apung Di Kolam Pasang Surut. Skripsi. Universitas Muhammadiyah Palembang. (Tidak dipublikasikan)

Manurung, A.P, Yusanti, I.A dan Haris, R.B.K. 2018. Tingkat Pertumbuhan dan Kelangsungan Hidup, pada Pembesaran udang galah (macrobrachium rosenbergii de man 1879) Strain Siratu dan Strain Gimacro II. Jurnal Ilmu-ilmu Perikanan dan Budidaya Perairan. 13 (2) : 27 - 36

Minggawati, I. 2006. Pengaruh Padat Penebaran yang Berbeda Terhadap Pertumbuhan Ikan Nila GIFT(Oreochromis $s p$ ) yang dipelihara dalam Baskom Plastik. Journal of Trofical Fisheries. 1(2) : 119-125.

Santoso, L. dan Agusmansyah. 2011. Pengaruh Subtitusi Tepung Kedelai Dengan Tepung Biji Karet Pada Pakan Buatan Terhadap Pertumbuhan Ikan Bawal Air Tawar (Colossoma macroponum). Jurnal Perikanan Terubuk. Pekanbaru. 39(2):4-50.

Sulistyansyah, Y. 2013. Pengaruh Pemberian Kalsium Karbonat $\left(\mathrm{CaCO}_{3}\right)$ Pada Media Bersalinitas Untuk Pertumbuhan Ikan Bawal Air Tawar (Colossoma macropomum) Skripsi. Institut Pertanian Bogor (Tidak dipublikasikan).

Wihardi, Y., Yusanti, I.A dan Haris, R.B.K. 2014. Feminisasi pada Ikan Mas (Cyprinus carpio) dengan Perendaman Ekstrak Daun-Tangkai Buah Terung Cepoka (Solanum torvum) pada lama Waktu Perendaman Berbeda. Jurnal Ilmu-ilmu Perikanan dan Budidaya Perairan. 9(1) : $23-28$

Yulianti, D. 2007. Pengaruh Padat Penebaran benih Ikan Bawal (Colossoma macropomum) Yang Dipelihara Dalam Sistem Resirkulasi Terhadap Pertumbuhan Dan Kelangsungan Hidup. Skripsi. Institut Pertanian Bogor (Tidak dipublikasikan). 